\title{
The African National Congress Led Government's (In)ability to Counter Public Corruption:

\author{
A Forensic Criminological Perspective
}

Setlhomamaru Dintwe

\section{Abstract}

Since the advent of democracy in 1994, there has been a myriad of incidents of corruption involving the public servants in South Africa. Equally so, the government led by the African National Congress have developed various mechanisms aimed at dealing with the problem of corruption. The incidents of corruption, characterized by colossal thefts, embezzlements and rampant bribery are the basis of erudition around the ability of the African National Congress led government in dealing with corruption. Although this article acknowledges the presence of corruption during the apartheid era, its crux is mainly on whether the programmes employed by the African National Congress proved adequate in turning the tide against the scourge of corruption, which tends to erode the fabric upon which the South Africa's economy is built. At the same breath, it is interesting to establish if the programmes employed by the ruling party encapsulate the internationally accepted elements reminiscent of an anti-corruption programmes worldwide. These elements are inter-alia, measurement of public perceptions, creation of public awareness, disincentivising corruption, visible sanctions, bureaucratic reform and most importantly, the political will in dealing with corruption. Corruption is an indicator of a defective system of public accountability which involves subversion of public interest for personal gains. An ability to deal with corruption manifests itself in two-fold paraphernalia. It encompasses understanding the causes of corruption on one hand and the calculated responses in countering corruption on the other. It is against this background that this article endeavours to establish the advancement of the African National Congress in dealing with corruption in government.

Keywords: Democracy, Public Corruption, Public Servant, Anti-corruption, South Africa. 


\section{INTRODUCTION}

The history of the African National Congress (ANC) dating hundred years back has seen the adoption and proliferation of vast economic policies and strategies based on a desire for equality of human race and observation of laws of natural justice. Some of these policies and strategies withered with time or assumed a different direction with the aim of adapting to the changing environment. Some persisted and started taking a visible shape after the ANC came to power in 1994. In government, the ANC adopted policies that were recognisably capitalist although its historic identification as a liberation movement remained necessary for it to maintain a certain ideological, or at least a rhetorical commitment to the schemas of old(Southall 2004:313). The few examples of the policies of the ANC led government which became subject of heated debates and contestation include the Black Economic Empowerment (BEE); the Affirmative Action (AA) as well is the ambiguities associated with the National Democratic Revolution (NDR). The main theory of the NDR argued that South Africa was a global player and needed to overcome racial oppression of black majority and build herself into a united nation based on the principles of democracy, transformation and societal equality. The ambiguities of the NDR emanated from a narrative that although the NDR was theorised as the precursor to socialism, the collapse of the Soviet style state socialist model emphasised that there was no 'Chinese wall' between capitalism and socialism (Cronin 1996:4).

Although the ANC existed for hundred years and experienced a myriad of changes, the main purpose of this article is to analyse its outlook after the white minority government conceded to democracy. This means that the ANC's ability to counter public corruption will be limited to a period between 1994 and 2012 . Public opinion and a number of official reports show that corruption is rampant in South Africa. This statement is not exclusive to the modern democratic South Africa but also a realisation that democratisation has reduced a level of secrecy in public affairs. It is therefore an attitude of this article that public corruption existed during the apartheid era but that the extension of government activities and adoption of different policies aimed at reversing the impact of apartheid opened up possibilities for abuse.

This article also looks at how corruption manifested itself after democratisation, how this affected the country at large and what are the responses of the ruling party as far as corruption is concerned. In addition to that, this article looks at the elements which define an effective anti-corruption programme internationally and whether these elements are present in the current mechanisms employed by the ANC led government. In each case, the 
author uses analysed literature to arrive at conclusions pertinent to the observation of the elements of an anti-corruption programme. In the final analysis, there will be erudition around specific actions of the ANC led government which may seem to contradict its will to counter corruption in South Africa.

\section{THEORETICAL FOUNDATION}

Dealing with corruption of any form is a very complex phenomenon normally influenced by both internal and external factors. As a result of this complexity it is often not easy to rely on a single theory in addressing the problem of corruption. Although there are main theories pertinent to corruption, this author chose only two which are commonly used to understand corruption and react to it in the public sector.

The first theory of dealing with corruption is known as the Principal-Agent theory where the employee or managers are incentivised by the owner in order to exert effort (Shar, 2007:256). Since this theory is based on the premise that good behaviour and performance should be compensated, its adverse means that those suspected or caught committing corruption will face light punishment such as a salary cut, or a mere attendance of an improvement programme. Although the punishment associated with this theory may not eliminate corruption, its advocates argue that the performance of employees would improve if such a theory is adopted. It is only fair that this kind of theory can only be used in minor case of corruption and where there is a hope that the perpetrators will mend their ways in the future. If an act of corruption is too harmful for any organisation this theory may not yield the necessary results. At the same breath, it is likely that if monitoring is not done sufficiently, this theory may be manipulated further. For instance, as illustrated by Shar (2007:256) a school teacher who favoured few students by marginally giving better grades may be difficult to detect. However, the adoption of the Principal-Agent theory comes into play when the likely consequences that reforms based solely on incontrovertible evidence of criminal wrongdoing are likely to be ineffective. On the other hand, this theory may even trigger corruption since even good employees inflate outcomes so they can receive incentives. This therefore means that this theory may have a 'give and take' effect in that it may bring about commitment among workers but may also affect an honest workmanship adversely.

The second theory of dealing with corruption is known as the Economics of Crime Theory which focuses on how potential criminals can be discouraged from 
committing crimes by severe punishment based on observable and verifiable behaviour (Shar, 2007:256). The difficulty of detecting corruption in the public sector and anywhere else must be taken into consideration in understanding the Economics of Crime Theory.

As alluded to earlier, an ideal approach in dealing with corruption which is often complex in nature is the combination of two theories. For instance, in the Principal-Agent theory, the policy maker chooses the desired quality and attempt to influence the decisions of the individual agents in such a way that the targets is eventually reached (Siebert, 2008:128) whilst the Economics of Crime theory can be used to predict how changes in the probability and severity of punishment and in a various social economic factors may affect the amount of corruption (Eide, Rubin \& Shepherd 2006:1).

It is therefore against this background that this article attempts to analyse how an anti-corruption programme should look like in pursuit of incorporating different theories of countering corruption. The problem underlying this analysis is that corruption is vastly different and the mechanisms of dealing with such must be differentiated as well. For instance, certain acts of corruption are criminal in nature whilst other acts may be a mere contravention of organisational internal policies. This article will therefore conclude that public corruption needs a multifaceted approach and not an over glorified theory at the disadvantage of the other.

\section{MANIFESTATION OF CORRUPTION}

Corruption in the ANC led government can be attributed to the proliferation of five groups that resulted immediately after the unbanning of exiled political parties and the dawn of democracy South Africa. These groups which included the 'educated excellence'; the 'Activist Capitalists'; the 'Corporate Sophisticates' as well 'Consultant of Change' saw a transference of the means of production and part of the wealth onto the hands of those who were previously marginalised (Randall 1996:666). Although these groups were admittedly without any independent base in the economy and that they were mainly employed in advisory non-operational positions, their ability to wield influence over government prepared the ground for the germination of post-apartheid public corruption. In addition to that, corruption can also be attributed to historical and cultural traditions, the manner of economic development in South Africa as well as the government policy and political institutions' culture. The spirit of this article is beyond a mere debate on whether corruption exists in the ANC led government. This is the reason why this article will not unravel around 
the levels of corruption in government but to look at what went wrong in the fight against corruption. An alternative argument is therefore that although much of the contemporary corruption may be inherited from the past, the democratisation of South Africa made her more vulnerable to public corruption.

Although there are many causes of corruption, for the purpose of this article corruption is primarily and collectively caused by institutional weakness. This means that in most cases corruption spreads because institutions are poorly developed; poorly enforced, rules are ambiguous and consequently leaders are not held accountable for their actions. This model of manifestations is reflective of the government under the leadership of the ANC. Institutional weakness, as argued by Eicher (2009:8) lead to bribery, nepotism and other undesirable behaviours. The breaking of the former Soviet Union is a good example of a weakened formal institution when almost everything such as laws, government agencies and Codes of Conduct were wiped out and had to be re-invented (Eicher 2009:8). It was during this period that new economic graft and rentseeking opportunities were created. It was also during this period when the politicians grabbed an opportunity of directing the state resources into their personal portfolios.

Manifestation of corruption in South Africa after 1994 cannot be differentiated from the weakened institution's analogy. It must be borne in mind that in 1993 and 1994, a lot of changes took place as a result of the negotiations for government of national unity and the first democratic elections. This was also the period that the ANC had to contend with legislative processes such as the enactment of the Constitution of the Republic of South Africa which was almost non-existent prior to democratisation. Other legislations which excluded the other population groups from participating in government had to be repealed and amended as well as being aligned with the Constitution. Over and above all these, the ANC leaders who were mainly from exile, had to be exposed to government leadership for the first time. It is therefore submitted that the South African government was reduced to a weakened institution around 1990's and past 1994. This is supported by Southall (2004:314) who argued that democracy had set in motion a rapid mobility whereby propertied and professional sections of the black community gained from advancement and that their relative advantage could easily render such elements anti-ethical to the interests of the poor. This therefore meant that there was a need for vigilance to prevent this black bourgeoisie from becoming the tools of monopoly interests, or parasites that thrive on corruption. It is also evident in the words of Pallo Jordan (1997:12) that the rising black bourgeoisie posed threats to ethical behaviour and the spirit of the ADR. The implication was that the ANC's engagement with an emerging 
black bourgeoisie should involve the elaboration of certain standards of conduct that will speed the realisation of the postponed goals of the national liberation movement.

In short, corruption manifests itself in many ways and at different levels. There is a broad range of corruption manifestation in tax administration, government expenditure programmes and other areas of fiscal policy and management (Martinez-Vazquez, Granado \& Boex, 2007: I X). Apart from these formal manifestations, corruption can also take a non-fiscal shape in which public officials abuse their public powers for private gains outside the realm of fiscal processes. Other examples include job reservations for spouses, children, family, siblings and relatives of parliamentarians and other influential people in government as well as bribery, fraud, theft, extortion and maladministration.

\section{THE EXTENT OF PUBLIC CORRUPTION}

Although there is a concession that the levels of corruption in South Africa are lower than most of sub-Saharan African countries, its extent is still sufficient to derail service delivery in South Africa. Although there are no arguments about the existence of corruption in South Africa, there is a desire to understand the extent of corruption in South Africa and to look at different avenues that can be employed in order to hamstring its growth.

Although difficult, there are a few ominous indications which can be used to measure the levels of corruption in South Africa. In 2010, South Africa was rated as the 54th most corrupt nation out of 178 countries surveyed (Transparency International 2008, 2010). The comments by senior government officials including Ministers and the Public Service Commission report (2002:27) confirmed that bribery, fraud, nepotism and systemic corruption are prevalent in contemporary South Africa. Other indicators of corruption include the results of different surveys, which all confirmed the prevalence of corruption in South Africa. For instance, a survey conducted by IDASA in 1996 showed that $46 \%$ of those surveyed felt that most officials were involved in corruption and only $6 \%$ believed that there was clean government (Lodge 1998:157). In another survey conducted by World Value Survey (1996:41) 15\% of the respondents were certain that all public servants were guilty of bribery and corruption whilst another $30 \%$ thought most officials were venal.

The few examples given indicate that corruption in South Africa is rampant by both reality and perception. There are many surveys and rankings which show the prevalence of corruption in South Africa but the few mentioned examples 
are sufficient for the purposes of this article to indicate the level of corruption in South Africa. It is therefore concluded that public corruption is located within the institutions of government including the Legislature, Courts, Bureaucracies and other statutory bodies including Parastatals and Commissions. Further than that, it is clear that corruption is constituted by transactions or exchanges of public resources and benefits between actors some or all of whom are officials or public representatives (Lodge 1998:158).

\section{AN ANTI-CORRUPTION PROGRAMME: A FORENSIC CRIMINOLOGICAL PERSPECTIVE}

Due to the multi-inter-transdisciplinary nature of this article, the ability of the ANC led government to deal with public corruption is looked at not only within the ambits public administration but also through the forensic criminological lenses. In forensic criminology the interest does not end with understanding a particular phenomenon but encompasses mechanisms aimed at reacting to a particular phenomenon. In this instance, the article is interested on whether the ANC was able to formulate an Anti-Corruption Programme similar to most of the democracies. In addition to that, erudition around this creation is coupled with the question of whether all the elements of an Anti-Corruption Programme have been observed by the ANC led government. The elements of an Anti-Corruption Programme are discussed and each time a conclusion is made as to whether such elements have been followed in letter and in spirit. Even in cases where there is enough progress, the author will seek to clarify some of the events which may adversely impact on these elements and generally the ANC's willingness and ability in dealing with public corruption.

\section{Measurement of public perceptions}

This refers to measuring the perceptions of citizens about the extent of public corruption in government. A good knowledge is critical in developing strategies aimed at combating corruption. The ANC led government denial and spindoctoring of corrupt activities have made the measurement of public perceptions very difficult over the years. It is often argued that the ANC is not corrupt but that it is individuals within the party and the government who are committing acts of corruption. As fair as it may sound, the argument of this article is that corruption has elevated itself to a level of a normal feature of official business. This means that, it is high time that authorities accept that there 
is corruption in government and stop regarding the incidents of corruption as sporadic and excluded. Statistics of corruption from different media has shown that corruption did not cease after the ANC took over government in 1994. Although this is the case, there is another school of thought which submits that although corruption still existed after 1994, very little was known about it. The reason advanced by the advocates of this thought is that after 1994, the people who were mostly affected were very poor and disenfranchised while the rich minority were unlikely to come face to face with public corruption. Most of the government agencies which were financed through government funds were not under strict scrutiny. For instance, out of 648 bodies financed through public funds only 34 reported to parliament whilst 200 bodies had to submit their records to parliament.

It is concluded that the ANC led government did not do enough when it comes to measuring the public perceptions about corruption. Most of the information which came from the independent research bodies was normally met with great denial by the ANC led government. Apart from low level researches and disintegrated investigations about perceptions of corruption, there are no other clear avenues that the ANC led government used to gauge the level of corruption in South Africa. Although the environment to report corruption became favourable after 1994 because of the removal of restrictions of public knowledge about government business and the opposition parties' commitment to expose corruption, the measurement of public perception about corruption still remained sporadic. Some of the agencies such as Institute for Democracy in Africa (IDASA), Human Sciences Research Council (HSRC), Institute for Security Studies (ISS) to mention but a few, kept on publishing research results indicating public perception about the prevalence of corruption. The results published by these agencies were not always accepted by the government. In addition to that, these interventions should have been initiated by the government itself as part and puzzle of an Anti-Corruption Programme. Although the public perceptions were partly measured by these independent agencies, the ANC led government cannot be said to have done enough in assessing what citizens of South Africa think about corruption. This vacuum is bad for any Anti-Corruption programme is repeated exercises of this nature and at repeated intervals; correlated with other indicators of institutional efficiency can reveal a good picture about corruption and guide the responses appropriate for such. 


\section{Creation of a public awareness}

The raising of public awareness should be allied with the promotion of ethical values and mobilisation of public interest in dealing with issues of corruption. This may include the utilization of non-governmental monitoring, anticorruption hotlines and a general civic participation. This is in line with the argument of Treitsman (2000:401) who submits that the 'legal culture' had an impact on the reduction of corruption and that this was more distinct in some of the former British colonies.

This trait has been seen since the ANC took over but the rate at which it was implemented was not without problems and delays. The recent one month old Corruption Watch launched by the Congress of South African Trade Unions (COSATU) is an example of such civic and non-governmental intervention. The fact that some of these bodies are still being formed eight years after the ANC took government is a clear indication of the chameleon pace at which this effort is been unfolding. The creation of awareness about corruption seems to be a known factor by the ANC led government but the implementation of such has been mired in troubles. For instance, the Mbeki administration called for a robust education campaign against corruption with the intention of creation of 'zero tolerance', 'total war', and 'morale submits but this never saw a systematic official campaign to educate the public about the nature and the consequences of corruption. At the same breath, the 1998 undertaking by the Public Service Commission to mount public campaigns to reinforce the 'fear of detection punishment', the 1999 resolution of the Anti-Corruption summit and the creation of the Anti-Corruption Forum did not bear desirable fruits because there were no clear plans for any State funding or that the resources allocated were rather modest (Lodge 2001:58).

Although there are Codes of Conduct for public servants and parliamentarians, these remain less publicised and the average citizens have no acumen for understanding these codes. The Ministerial Handbook is one of such initiatives which to date remains unclear and greatly contested. The greatest drawback in awareness is the failure by the ANC government to disclose its disciplinary cases involving corrupt officials and repudiation of nongovernmental interventions. For instance, in November 2000 the then Minister Steve Tshwete repudiated a proposed private sector agency to monitor police corruption. The actions of the Minister further justified maintenance of the tollfree anti-corruption hotline by the South African Police Service and Gauteng government (Lodge 2001:59). The failure to create public awareness and 
involvement in anti-corruption initiatives is a setback for any anti-corruption programme.

\section{Disincentivising corruption}

This has also been a hallmark of many Anti-Corruption programmes worldwide. It may involve improving salaries of politicians and public servants but in South Africa it may mean a total review of the tendering and procurement processes. Statistics have shown that most of the money lost to corruption happens during tendering and the procurement of services. For instance, the Special Investigating Unit claimed that the R10 Billion worth of fraud that it was investigating 1998 only represented $5 \%$ of the total cost of corruption. The very same trend of procurement fraud was also experienced in the delivery of lowcost housing to an extent that this have drawn comments and concern of the current Minister of Human Settlements, Tokyo Sexwale (Rubin 2011:483).

An effective Anti-Corruption programme should be able to identify gaps in the procurement systems and try to disincentivise corruption where it is imminent. This, in South Africa could be achieved by a reduction of outsourced services such as the provision of water, sanitation, health and housing facilities. There is no doubt that exorbitant amounts of money have been squandered whilst claiming to pay the service providers. It is therefore submitted that if most of the mainstream services were provided by government departments, then there would be less incentives associated with corruption. The construction of roads in South Africa and particularly in the North West province have shown that a lot of graft could have been prevented if the government was in the forefront of rolling out such services. According to Lodge (2001:60) with the government's retreat from the 'dirigiste' models of public administration favoured under apartheid, the proliferation of privatisation and the contracting out of what were exclusively government functions, the government's regulatory functions have expanded rapidly, well beyond its administrative capacity.

\section{Visible sanctions}

Corruption cannot disappear mainly through the reaction by law enforcement but there must also be some deterrence to the prospective transgressors. Since the theories of dealing with corruption suggests two alternatives in punishing those guilty of corruption, visible sanctions means criminalising some of the 
activities which are dealt with through internal departmental disciplinary procedures. Different means of punishment such as criminal sanctions, dismissals and recovery of losses from the individual's assets must be meted out. This punishment must also be seen to be applied to those who are seen as senior or politically connected. Visible sanctions are based on the premise that deterrence is accomplished through a variety of efforts associated with internal controls and ethic programmes that create a workplace of integrity and encourage employees to report potential wrongdoing (Kranacher, Riley \& Wells 2011:13).

The confronting question here is question here is on how much has the ANC led government progressed in ensuring that those who are accused of corruption are visibly punished thereby deterring the prospective wrongdoers? The conclusion is that the current state of affairs leaves behind a lot to be desired. The wheels of justice are grinding at the lowest pace and most of those accused of corruption escape unscathed due to prolonged criminal justice processes. The following are the examples of how the sanctions imposed on those suspected and accused of corruption may not be visible to the general public:

- Officials remain on payroll while the prosecution is protracted,

- In Mpumalanga, the scandal involving the Testing Station was so prolonged to an extent that a person who exposed it, John Muller was removed from his post before the case could be finalised,

- Organised labour such as the Police and Prison Civil Rights Union (POPCRU), South African Police Union (SAPU) and others continue to protect their members amid allegations of corruption. For instance, POPCRU labelled a dismissal of Commissioner Khulekani Sithole as a loss of the most committed and dedicated civil servant,

- Police officials can only be dismissed after they have been found guilty and an imprisonment has been mandated. The affairs and processes surrounding the case of suspended Commissioner of the Police; Bheki Cele is an example of such.

Although there is an acknowledgement of the ANC led government's will to deal with corruption through protection the whistle blowers, the constitutionally protected offices of the Auditor General, Public Protector and establishment of 
the Special Investigating Unit, the problem still lies with whether the visible sanctions are being meted out. The danger around delayed prosecution is that at the time the court passes judgement and sanctions, a particular issue has already lost its newsworthiness. This therefore means that the citizens may not even be aware that a particular individual was sanctioned for public corruption. The investigation of arms deal in South Africa is a prominent example of delayed justice processes which can upset the visibility sanctions.

\section{Bureaucratic reform}

Political appointments, exodus of skilled managers from the public service, affirmative action and in certain instances the employment equity, if not implemented judiciously can compromise the integrity of the civil service. Due to this compromise and lack of skills in the public service especially in the times that the public service has grown to be complicated can lead to serious gaps in management systems and thereby allowing graft to flourish. Although the ANC led government may outgrow this problem of political bureaucracy, it is currently known that there are challenges of leadership and skills shortages in the public sector. For instance, the Auditor General's reports annually indicate that public funds are not in order and this is frequently attributed to shortage of accounting skills in the public sector.

Any effective Anti-Corruption programme takes the issue of leadership and the deployment of skilled people seriously. It is therefore concluded that due to political appointments, the ANC led government did not progress adequately in embracing this effort of an Anti-Corruption programme. There have been cases where municipal managers were dismissed from one municipality for public corruption but only to be recruited by another municipality. This is unfortunate because although the ANC led government has tried its best in sourcing necessary skills and reforming different bureaucracies, the number of negative moves seems to be higher than the good.

\section{Political will}

The ANC led government cannot keep on claiming that they believe in the clean government and working towards such if there is no clear indication of political will to turn the tide against corruption South Africa. The establishment of different agencies and development of policies and strategies aimed at dealing with corruption cannot be suffice if senior ANC official continue to criticise the 
decisions of the courts and other tribunals when their members are involved in corruption. This trend has been clear since 1994 and in certain instances the judges are being labelled counter-revolutionary if their decisions seem to contradict the aspirations of the ANC leadership. This effort of an Anti-Corruption programme is therefore creating mixed feelings in South Africa because the government reiterates the willingness to deal with corruption while at the same time the comments of senior ANC officials undermine the same political will. Unfortunately, all negative moves by the political leadership in criticising the outcomes of independent bodies overshadow all efforts by the ruling party to succeed in establishing a profound Anti-Corruption programme.

Lodge (2001:62-63) summarises the actions of the ruling party which contradicts the political will to deal with corruption:

- In 1999, the Minister of Energy, Penuel Maduna lashed out at the Auditor General and concluded that Auditor General had grossly misrepresented the accounts of the Strategic Fuel Fund. Although these allegations by the Minister were proved to be untrue later, no withdrawal was ever forthcoming from the then Minister. Although in other democracies this move by the Minister of Energy could have tarnished his political vigour, the same minister was appointed as the Minister of Justice by the Mbeki administration after 1999. One of his other judicial blunders as far as corruption is concerned was his hinting that he might shut down the then Heath Commission now known as the Special Investigating Unit,

- In the same year, the South African courts were lambasted by the ANC through its spokesperson, Smuts Ngonyama who questioned the integrity the level of transformation of these courts. This was after Allan Boesak, the then ANC leader was found guilty of embezzling the monies of the charity organisation he was heading. Ngonyama alluded that Boesak's main 'sin' was his 'lack of accounting skills'. As if that was not enough an attack by the ANC on the corruption busting mechanisms, Ngonyama went further and accused the Appeals Court as being totally biased after Boesak's conviction was confirmed. As a matter of fact, the ANC bigwigs attended a church service in numbers presided by Allan Boesak after his release from prison in May 2000,

- In 1999, the Mpumalanga News (1989) ran an interesting story of the reappointment of the disgraced members of the Executive Council (MEC's). These MEC's were previously implicated in earlier corruption 
scandals. Although the then premier of Mpumalanga, Ndaweni Mahlangu said the people he had chosen 'the best team', this was a setback in the fight corruption. This trend is still continuing and an example is that of a municipal manager of Mangaung who was deployed to Ngaka Modiri Molema while he was still being investigated for corruption. All these actions are surely equivalent to a setback in trying to convince the citizens that the ANC that government is intolerant to corruption,

- In addition to these acts which contradict the political will to deal with corruption, the issue of political appointments, secrecy about electioneering funding and the retention as well as open praises about some of the Director Generals despite revelations about their involvement in corruption amount to a shadow which obscures the ANC led government's political will to deal with public corruption.

Although the few examples given thus far may be contradicted by other good moves by the ANC led government, the crux of the matter is that the political will in dealing with corruption must be clear and consistent. It must be seen and followed both in letter and spirit. It is unfortunate that although some executive managers and Ministers were recently axed such as the late Sicelo Shiceka and Gwen Mahlangu-Nkabinde, this happened after a serious calling and pressure from some of the opposition parties. It is against this background that it is concluded that the political will in dealing with corruption by the ANC led government is tainted, skewed, inconsistent, minimal and less visible.

\section{CONCLUSION}

From the literature gathered and analysed, the ANC led government did not succeed in turning the tide against corruption since it took over government in 1994.. This means that the Anti-Corruption strategies adopted by the ANC led government fell short of being effective as some of the important facets and elements were compromised, ignored and not implemented. An Anti-Corruption Programme is a set of action which must all be observed equally if any democracy is truly committed to addressing corruption and its repercussions on service delivery, political stability and the well being of the entire country. It is clear from the preceding discussion that some of the elements were observed whilst other remained to chance. The events which have been reported in the myriad of media are justifications of this conclusion. The desire of the ANC led 
government to deal with public corruption is characterised by opacity, confusion and capriciousness which exacerbates the picture regarding the ANC led government's will to thwart corruption and reverse its adverse impact on the ordinary citizens.

The analysis is deemed fair and fit as the ANC has been in government for a considerable number of years. Even in cognisance of the inheritance of public form the apartheid era, a more willing government would have reduced corruption tremendously as corruption weakens the corporate governance principles desired by any democracy. Although there are positive aspects such as the establishment of several corruption busting bodies, enactment of anticorruption legislation such as The Prevention and Combating of Corrupt Activities Act, Act 12 of 2004 and the recently launched non-governmental Corruption Watch of COSATU, the level of corruption in country continue to reach epidemic levels.

In conclusion, and agreeing with Lodge (1998:161) the ANC government is still haunted by bureaucratic secrecy, the absence of mutual surveillance procedures by government agencies, protracted rule by one political party or an ageing one party dominant system, administrative inefficiency, complicated hierarchical decision-making procedures which create lengthy delays and extensive patterns of political appointment in the civil service. All these enemies are adverse to any Anti-Corruption Programme and leave marginal opportunity for all corruption fighting mechanisms to succeed.

\section{List of References}

- Cronin, J. 1996. Thinking about the concept 'National Democratic Revolution, Umrabulo, 4.

- Eicher, S. 2009. Corruption in International business: The challenge of cultural and legal diversity. Surrey: Ashgate Publishing Ltd.

- Eide, E; Rubin, P.H \& Shepherd, J.M. 2006. Economics of crime. Hanover: now Publishers.

- Jordan, P. 1997. The national question in post 1994 South Africa: A discussion paper in preparation for the ANC's 50th National conference. Available on www.anc. org/ancdocs/discussion/natquestion.html. Accessed 14 January 2012. 
- Kranacher, M; Riley, R \& Wells, J.T. 2011. Forensic accounting and fraud examination. New York: ACFE.

- Lodge, T. 1998. Political corruption in South Africa. Journal of African Affairs, 97(3).

- Lodge, T. 2001. Countering public corruption in South Africa. Available at http:// archive.lib.msu.edu/DMC/African\%20journals/pdfs. Accessed 15 January 2012.

- Martinez-Vazquez, J; Granado, J.A \& Boex, J. 2007. Fighting corruption in the public sector. Amsterdam: Elsevier.

- Public Service Commission. 2002. A review of South Africa's National AntiCorruption Report, Annexure 3. Pretoria: Department of Public Administration.

- Randall, D.J. 1996. Prospects for the development of a black business class in South Africa. The journal of modern African studies, 34(4).

- Shar, A. 2007. Public Sector Governance: Performance accountability and combating corruption. Washington: The World Bank.

- Siebert, H. 2008. Economics of the environment: Theory and policy. Berlin: Springer- Verlag.

- Southall, R. 2004. The ANC and black capitalism in South Africa. Review of African Political Economy, 31(2).

- Transparency International. 2008. Corruption perception index. Available at http://www.transparency.org/policy_research/surveys_indices/cpi/2008. Accessed 15 January 2012.

- Treisman, D. 2000. The causes of corruption: A cross-national study. Journal of Public Economics, 76 (2000).

\section{AUTHOR DETAILS:}

\section{SETLHOMAMARU, Isaac Dintwe}

